\title{
Keterkaitan Perkembangan Permukiman dan Perubahan Harga Lahan di Kawasan Tembalang
}

\author{
Dodi Pidora1 \\ Kementerian Perindustrian \\ DKI Jakarta, Indonesia
}

\section{Bitta Pigawati}

Jurusan Perencanaan Wilayah dan Kota

Universitas Diponegoro, Semarang, Indonesia

\begin{abstract}
Abstrak: Kawasan Tembalang diarahkan sebagai lokasi kawasan pendidikan, khususnya perguruan tinggi. Hal ini menjadi daya tarik penduduk untuk menempati kawasan ini dan berakibat pada peningkatan kebutuhan ruang. Peningkatan kebutuhan lahan untuk permukiman, perdagangan dan jasa, berakibat pada peningkatan harga lahan di kawasan tembalang. Tujuan dari penelitian mengkaji keterkaitan antara perkembangan permukiman dengan perubahan harga lahan. Penelitian ini menggunakan metode kuantitatif dan analisis spasial. Keterkaitan perkembangan permukiman dan perubuhan harga lahan menunjukan adanya korelasi bernilai 0,45 (Pearson Correlation). Perkembangan permukiman umumnya berada di harga lahan rendah, dan secara langsung memberikan efek pada peningkatan harga lahan. Perkembangan permukiman paling tinggi berada di radius $1-2 \mathrm{Km}$ mencapai $204 \%$ pada tahun 2012. Perubahan harga lahan sendiri menunjukkan peningkatan yang sangat tinggi. Khususnya di daerah yang memiliki kedekatan jarak dari Kawasan UNDIP seperti di Kelurahan Bulusan meningkat hingga sebesar 800\% dari 2002 ke 2012.
\end{abstract}

Kata Kunci: Kawasan Pendidikan, Perkembangan Permukiman, Perubahan Harga Lahan.

\begin{abstract}
Tembalang area is planned as location for education, especially for high level education. This function becomes a pull factor for the population to occupy the land which leads to the increase of needs for supporting space. The increase of space requirement for the development of settlement, trade, and service area bring an impact to the land price rising in Tembalang. This research aims to find out the correlation between the settlement development with the land price evolution. The method used is quantitative with the support of spatial analysis. The correlation of settlement development and land price evolution is observed with the score of 0,45 as Pearson Correlation. The correlation is represented mostly in lower land price which directly give effect to the price rising. The largest land expansion for settlement is in radius 1-2 Km which reaches 204\% in 2012. Whilst, the land price itself experiences very high increase, especially in the area situated close with UNDIP such as Bulusan Village where the price rising hits 800\% from 2002 to 2012.
\end{abstract}

Key word: education area, expansion of residential area, land price evolution

\footnotetext{
${ }^{1}$ Korespondensi Penulis: Kementerian Perindustrian, DKI Jakarta Email: dpidora@gmail.com
} 


\section{Keterkaitan Perkembangan Permukiman dan Perubahan Harga Lahan di Kawasan Tembalang}

\section{Pendahuluan}

Perkembangan permukiman yang terjadi pada setiap bagian kota berbeda satu sama lain. Hal tersebut dipengaruhi oleh karakteristik kehidupan masyarakat, potensi sumber daya dan kesempatan kerja yang tersedia, kondisi fisik alami serta ketersediaan fasilitas kota. Pemanfaatan lahan untuk perumahan dan permukiman di daerah perkotaan mempunyai proporsi yang lebih besar jika dibandingkan dengan jenis pemanfaatan lainnya. Permukiman dibangun dengan maksud untuk mengatur manusia berkehidupan di dalam ruang alam dan berinteraksi dengan alam dalam rangka mencapai kemajuan kehidupannya. Dalam pemanfaatan lahan, kawasan permukiman merupakan salah satu sektor yang memegang peranan penting dalam perekonomian nasional dan merupakan unsur dari kebijakan sosial nasional (White, 1988).

Kebutuhan rumah dan fasilitas pendukung untuk permukiman secara langsung mengurangi ketersediaan lahan di Indonesia. Kebutuhan ruang untuk hunian setiap tahunnya dipastikan meningkat seiring dengan pertumbuhan jumlah penduduk dan keluarga baru. Data statistik menunjukkan bahwa pertumbuhan jumlah keluarga baru di Indonesia rata-rata sekitar 800 ribu keluarga per tahun sementara pihak Developer (REI) dan Perum Perumnas hanya mampu membangun rumah rata- rata sekitar 200 ribu unit per tahun, artinya hanya $25 \%$ dari kebutuhan yang dapat terlayani oleh penyedia perumahan (REI dan Perum Perumnas). Hingga kini diperkirakan Indonesia mengalami backlog atau akumulasi kekurangan rumah setiap tahun sekitar 6 juta unit rumah (Sutrisno, 2007). Pemilihan lokasi permukiman harus memperhatikan beberapa faktor agar tercipta kawasan permukiman yang aman, nyaman, dan berkelanjutan. Faktor yang perlu dipertimbangkan diantaranya meliputi kondisi fisik alam, sosial ekonomi, dan faktor politik yang berkaitan dengan keterkaitan antar wilayah. Kondisi fisik alam diantaranya mencakup kondisi topografi, iklim, kondisi geologi dan kondisi fisik lain. Kondisi sosial ekonomi misalnya sebaran penduduk, tingkat kesempatan kerja, dan kondisi guna lahan eksisting.

Lokasi di sepanjang tepi jalan merupakan lokasi yang strategis untuk melakukan aktivitas karena memiliki aksesbilitas yang tinggi. Dengan semakin banyaknya aktivitas di lokasi tersebut, maka lahan di sekitarnya yang jumlahnya terbatas akan diperebutkan agar dapat diperoleh keuntungan yang maksimal. Persaingan tersebut akan menjadikan nilai lahan meningkat. Nilai lahan adalah suatu penilaian atas lahan yang didasarkan pada kemampuan lahan secara ekonomis dalam hubungannya dengan produktivitas dan strategi ekonominya (Drabkin dalam Yunus, 2002). Perubahan guna lahan, harga lahan dan nilai lahan di sepanjang jalan akan lebih tinggi dan pekembangannya akan lebih cepat.

Beberapa tahun terakhir, perubahan guna lahan dan harga lahan di kawasan Undip Tembalang menunjukkan suatu fenomena yang menarik. Penggunaan lahan yang sebelumnya berupa ruang terbuka, pertanian, dan lahan kosong, berubah menjadi permukiman dan perdagangan jasa yang dinilai memiliki nilai komersial yang lebih strategis dan kompetitif. Perubahan guna lahan ini memberikan peluang naiknya harga lahan di kawasan Undip Tembalang. Berdasarkan Suara Merdeka tanggal 17 Juni 2012, harga jual tanah di sekitar Kawasan Banjarsari yang sekarang mencapai Rp 3 juta naik menjadi Rp 4,5 juta per meter persegi. Kemudian tanah di Jalan Sirojudin dari sekitar Rp 4 juta menjadi Rp 5 juta, lalu di sekitar Politeknik yang sebelumnya Rp 5 juta naik menjadi Rp 6 juta.

Di wilayah penelitian ada beberapa pendidikan tinggi dan akademi yang sudah berkembang, antara lain: Universitas Diponegoro, Universitas Pandanaran, Politek Negeri Semarang, dan Politekkes Negeri Semarang. Jumlah mahasiswa Undip yang mencapai lebih dari 40 ribu tentu menjadi prospek cerah untuk mengembangkan usaha, seperti koskosan, warung makan, warung internet atau warnet, fotokopi, laundry, dan kafe sehingga semakin berpeluang meningkatkan nilai lahan yang ada. 
Pada kenyataannya, harga lahan di kawasan Undip Tembalang sudah mencapai nilai yang jauh lebih tinggi dari Nilai Jual Objek Pajak (NJOP) yang ditetapkan. Hal ini dikarenakan lahan merupakan barang ekonomis yang ketersediaannya terus berkurang setiap tahunnya. Sesuai dengan hukum pasar, ketersediaan suatu barang akan berbanding terbalik dengan nilai ekonomi yang dimiliki sehingga dengan semakin terbatasnya lahan maka nilai ekonominya akan semakin tinggi.

Keterkaitan antara perubahan guna lahan dan harga lahan di Kawasan Tembalang ini menjadi menarik untuk dikaji karena dapat menunjukkan seberapa besar perubahan guna lahan tersebut dalam mempengaruhi nilai lahan yang ada.

\section{Metode Penelitian}

Penelitian dilakukan dengan pendekatan spasial untuk mengidentifikasi perkembangan ruang fisik permukiman dan peningkatan nilai ekonomi lahan (harga lahan). Analisis dilakukan secara kuantitatif dengan bantuan data yang diperoleh dari survey lapangan secara langsung.

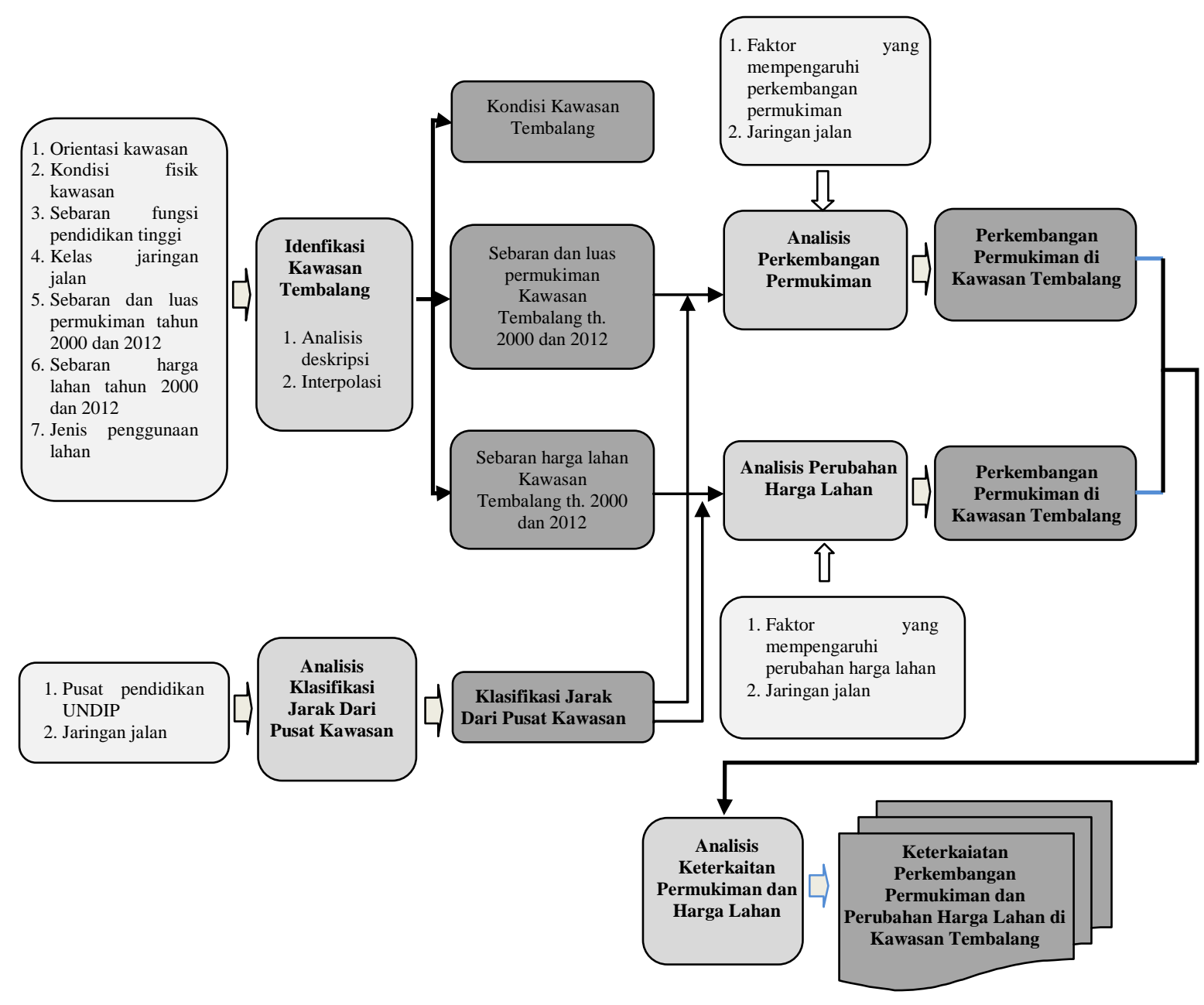

Gambar 1. Kerangka Analisis Penelitian 


\section{Keterkaitan Perkembangan Permukiman dan Perubahan Harga Lahan di Kawasan Tembalang}

Tahapan penelitian terdiri dari interpretasi citra satelit kawasan tahun 2000 dan 2012 dan harga lahan pada tahun 2000 dan tahun 2012. Selanjutnya melakukan analisis korelasi pada perubahan haraga lahan dan perkembangan permukiman di Kawasan Tembalang. Secara skematik, tahapan analisis dapat dilihat di Gambar 1.

Menurut Doxiadis (1974), permukiman merupakan bagian dari lingkungan hidup. Lingkungan terdiri dari banyak unsur, baik dalam zona lingkungan alam maupun bagian yang terbangun. Di dalam suatu lingkungan, selain kekuatan fisik, terdapat pula kekuatankekuatan sosial, ekonomi dan politis yang berdampak terhadap kehidupan manusia hingga akhirnya membentuk suatu pola permukiman. Berdasarkan sumber berbagai literatur ada beberapa faktor dalam pemilihan lokasi permukiman yang dapat dikelompokkan menjadi faktor fisik/alam, faktor aksesibilitas, faktor sosial ekonomi, faktor sarana prasarana, serta faktor lingkungan.

Pengertian lahan menurut Jayadinata (1999) merupakan tanah yang sudah ada peruntukannya dan umumnya dimiliki dan dimanfaatkan oleh perorangan atau lembaga untuk dapat diusahakan. Sedangkan menurut Cooke (Dalam Riza 2005) lahan merupakan keseluruhan kemampuan muka daratan beserta segala gejala di bawah permukaannya yang berhubungan dengan pemanfaatannya bagi manusia. Menurut Chapin (Ernawati, 2002), pola dan struktur nilai tanah kota dikemukakan sebagai berikut:

- Pusat wilayah (Central Business District) mempunyai nilai tanah tertinggi dibandingkan wilayah lain.

- Pusat wilayah kerja dan pusat perkotaan yang terletak disekeliling perbatasan pusat kota mempunyai nilai tanah tertinggi setelah CBD.

- Di luar dari kawasan tersebut, terdapat kawasan perumahan dengan nilai tanah yang semakin jauh dari pusat kota semakin berkurang nilai tanahnya.

- Pusat - pusat pengelompokkan industri dan perdagangan yang menyebar mempunyai nilai tanah yang tinggi dibanding dengan sekelilingnya, dimana biasanya kawasan ini dikelilingi perumahan.

Pengertian nilai tanah dibedakan antara tanah yang diusahakan (improved land) dan tanah yang tidak diusahakan (unimproved land). Nilai tanah yang tidak diusahakan adalah harga tanah tanpa bangunan diatasnya. Sedang nilai tanah yang diusahakan adalah harga tanah ditambah dengan harga bangunan yang terdapat di atasnya (Sukanto dalam Ernawati, 2005). Menurut Riza (2005), harga sebidang tanah ditentukan oleh jenis kegiatan yang ditempatkan di atasnya dan terwujud dalam bentuk penggunaan tanah. Harga tanah dalam keadaan sebenarnya dapat digolongkan menjadi harga tanah pemerintah (Goverment Land Price) dan harga tanah pasar (Market Land Price).

Pengertian sederhana Sistem Informasi Geografis (SIG) adalah sebuah sistem untuk pengelolaan, penyimpanan, pemrosesan, analisis dan penayangan (display) data yang terkait dengan permukaan bumi

\section{Hasil dan Pembahasan}

Analisis yang dilakukan, terdiri dari Analisis Klasifikasi Jarak dari Pusat Kawasan Tembalang, analisis perkembangan permukiman, perubahan harga lahan dan Anasisis Keterkaitan Permukiman dan Harga Lahan. 


\section{Klasifikasi Jarak Dari Pusat Kawasan Tembalang}

Penelitian ini menetapkan lokasi UNDIP sebagai pusat atau titik nol (0) dalam klasifikasi jarak dan dengan menggunakan Network Analysis pada ArcGIS dengan memanfaatkan jaringan jalan sebagai arus atau jarak dari titik nol/pusat kawasan (UNDIP). Klasifikasi jarak yang digunakan dalam penelitian ini terdiri dari tiga kelas yaitu radius kurang dari 1 $\mathrm{Km}, 1-2 \mathrm{Km}$ dan lebih dari $2 \mathrm{Km}$. Klasifikasi jarak dari pusat ini memudahkan dalam pembagian wilayah. Mengacu pada teori harga sewa lahan yang berbanding terbalik dengan jarak dari pusat (Chapin dalam ernawati, 2002).

\section{Perkembangan Permukiman}

Analisis perkembangan permukiman menggunakan interpretasi citra quick Bird tahun 2000 dan 2012. Hasilnya mengacu pada jenis tutupan lahan terbangun dengan fungsi permukiman, dan peruntukan jasa fungsi permukiman (kos dan guest House). Perkembangan permukiman dari tahun 2000 hingga tahun 2012 sebesar 168,65 Ha, atau mencapai $174 \%$. Berdasarkan penelitian yang dilakukan Pigawati (2011) tercatat alih fungsi lahan pertanian sebesar 34,91 Ha dan Lahan Kosong sebesar 122,96 Ha untuk Kecamatan Banyumanik dan Kecamatan Tembalang dalam kurun waktu tahun 2006 hingga tahun 2011

Wilayah radius kurang dari $1 \mathrm{Km}$ perkembangan permukiman mencapai 9,78 $\mathrm{Ha}$ atau sebesar $171,76 \%$ dari tahun 2000. Jika dibandingkan dengan pertumbuhan di wilayah radius lainnya, radius $<1 \mathrm{Km}$ merupakan wilayah yang paling sedikit mengalami perkembangan dalam hal luas permukimannya. radius $1-2 \mathrm{Km}$ hingga tahun 2012 bertambah sebesar 49,54 Ha atau meningkat hingga 204, 96\% dari tahun 2000. Radius $>2$ $\mathrm{Km}$ dari pusat kawasan pada tahun 2012 sebesar 176,47 Ha atau 25,75\% dari total luas lahan pada radius $>2 \mathrm{Km}$. Jika dibandingkan dengan tahun 2000, perkembangan permukiman di bagian kawasan ini bertambah sebesar 109,34 Ha dengan tingkat perkembangan sebesar $162,88 \%$.

Faktor yang mempengaruhi perkembangan permukiman di kawasan Tembalang adalah:

a. Dimensi lokasi (Aksesibilitas)

Menilik dari jalur lintasan atau jaringan jalan yang ada di Kawasan Tembalang terdiri dari jalan arteri primer yaitu Jalan Setia Budi, jalan arteri sekunder yaitu Jalan Ngesrep Timur V, Jalan Prof. Soedarto, Jalan Sirojudin dan Jalan Banjarsari, jalan kolektor sekunder yaitu Jalan Tirto Agung dan Jalan Durian, selanjutnya Jalan Tol Semarang-Solo. Untuk Jalan Tol, Kawasan Tembalang memiliki 2 akses pintu tol, yaitu Pintu Tol Tembalang dan Pintu Tol Banyumanik. Keberadaan jaringan jalan yang cukup kompleks di Kawasan Tembalang menambah nilai lokasional dari kawasan.

b. Pembangunan Perumahan

Pada tahun 2000 jumlah perumahan yang ada di Kawasan Tembalang adalah 12 perumahan. Namun pada tahun 2012, jumlah perumahan yang ada di Kawasan Tembalang mencapai lebih dari 25 perumahan (permukiman teratur) yang tersebar hampir di seluruh wilayah. Perkembangan perumahan selain jumlah perumahan yang bertambah, beberapa perumahan yang sudah ada juga memperluas wilayahnya, seperti perumahan Graha Estetika yang masih terus berjalan pembangunannya hingga saat ini. Secara spasial sebaran permukiman teratur berupa perumahan di Kawasan Tembalang berada di radius $>2 \mathrm{Km}$ mencapai lebih dari $153 \mathrm{Ha}$ atau $85,88 \%$, dari keseluruhan lahan peruntukan perumahan, sebanyak $1,02 \%$ berada di radius $1-2 \mathrm{Km}$, sisanya sebesar $13,11 \%$ berada di radius $<1 \mathrm{Km}$. 


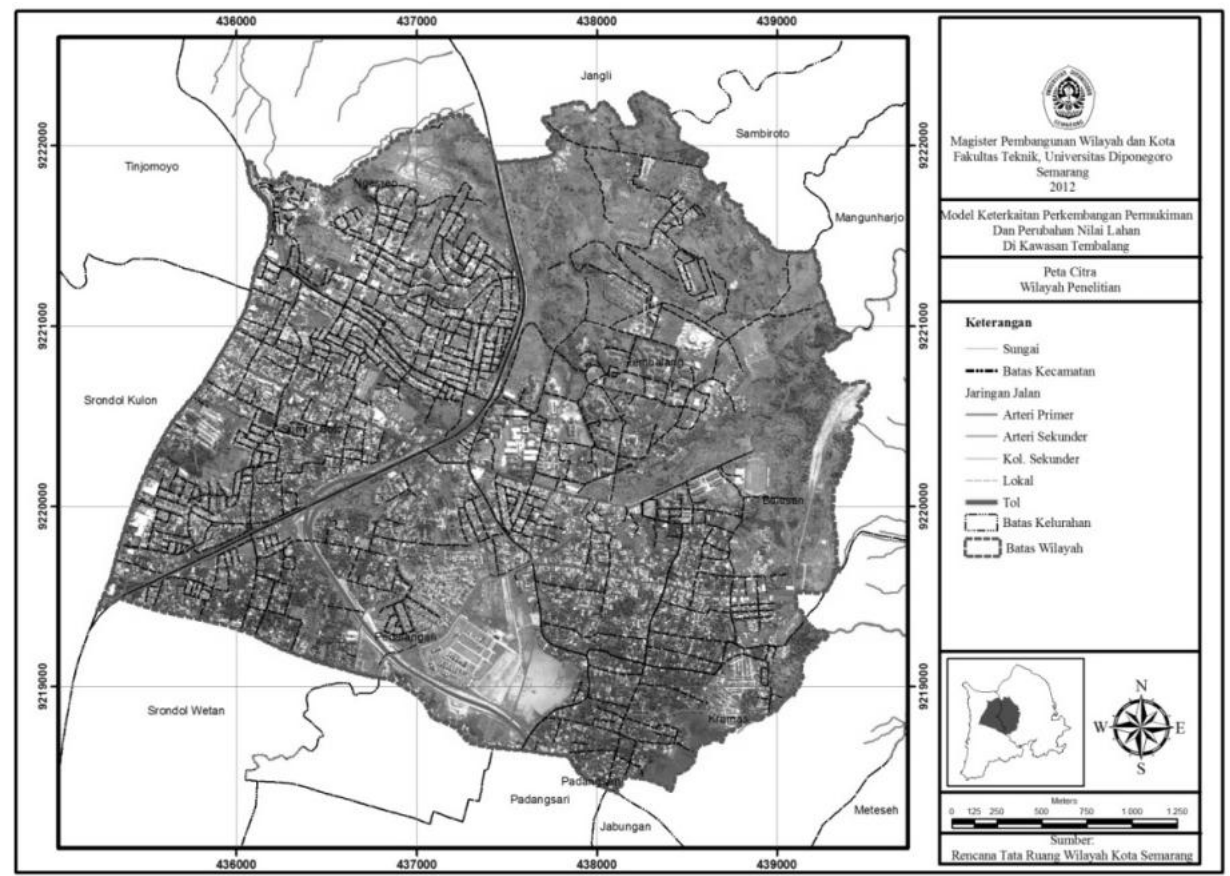

Sumber: Google Earth, 2013

Gambar 2. Citra Kawasan Tembalang Tahun 2011

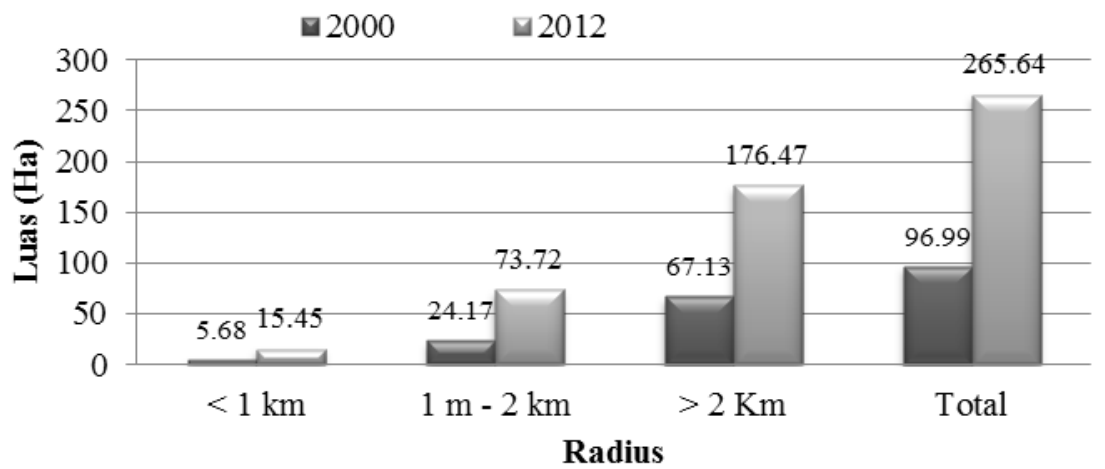

Gambar 3. Grafik Luas Permukiman Tahun 2000 dan 2012

\section{Perubahan Harga Lahan}

Data harga lahan di kawasan tembalang menggunakan data primer, hasil penyebaran kuesioner pada 108 sampel. Selanjutnya dilakukan interpolasi untuk melakukan generalisasi pada sebaran sampel.

Perubahan harga lahan di bagian kawasan dengan radius $<1 \mathrm{Km}$ dari pusat Kawasan Tembalang hampir merata pada persentase kenaikan $200 \%$ sampai $600 \%$. Rata rata perubahan harga lahan pada radius $<1 \mathrm{Km}$ adalah 447\% dari tahun 2000 hingga 2012.Beberapa faktor yang mendukung peningkatan harga lahan di radius kurang dari 1 $\mathrm{Km}$ adalah keterkaitan dengan jarak lahan dari kawasan pendidikan dan Nilai aksesbilitas. pada radius 1-2 $\mathrm{Km}$ dari pusat Kawasan Tembalang tertinggi berada di kelompok 
peningkatan harga 100\% - 400\% dengan persentase mencapai $82 \%$ dari luas lahan. Di radius ini juga di temukan sebagian kecil kenaikan harga lahan mencapai $900 \%$. Perubahan harga lahan di radius $>2 \mathrm{~km}$ dari pusat kawasan Tembalang mengalami peningkatan harga tertinggi sebesar 100-200\% dengan persentase 62,28 \% diikuti kenaikan 200-300\% sebesar $24,39 \%$ dan $11,24 \%$ mengalami perubahan harga sebesar $300-400 \%$.

Perbandingan jarak atau radius lahan dengan pusat Kawasan Tembalang terlihat perngaruh yang jarak dengan perubahan harga lahan yang berbanding lurus. Temuan ini masih sesuai dengan teori harga sewa lahan von Thunen, harga lahan tinggi di pusat kawasan dan akan makin menurun apabila makin jauh dari pusat kawasan (Yunus, 2002).

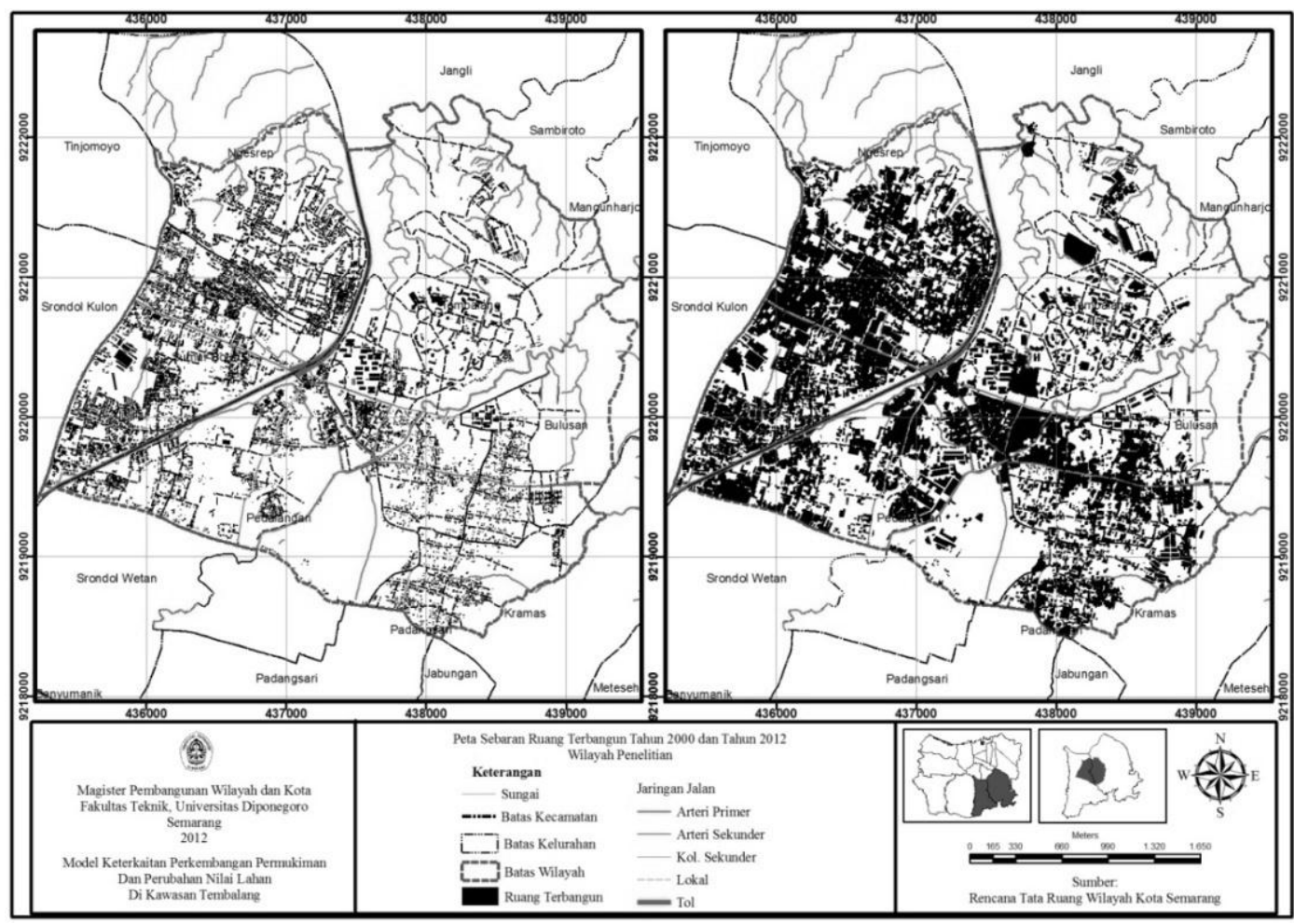

Gambar 4. Sebaran Permukiman Kawasan Tembalang Tahun 2000 dan 2012

\section{Keterkaitan Permukiman dan Harga Lahan}

Analisis ini untuk melihat keterkaitan antara perkembangan permukiman dan perubahan harga lahan di Kawasan Tembalang. Analisis ini membandingkan perkembangan permukiman dengan perubahan harga lahan (kelas) di masing-masing kelurahan. Menggunakan analisis korelasi untuk melihat keterkaitan antara dua variabel tersebut.

Hasil analisis korelasi parametrik menunjukkan nilai korelasi untuk variabel perubahan harga lahan dan perkembangan permukiman. Nilai korelasi antara dua variabel tersebut berdasarkan nilai perason correlation adalah $-0,459$. Hasil ini menunjukan adanya keterkaitan antara perkembangan permukiman dengan perubahan harga lahan serta sebaliknya dengan kekuatan korelasi sebesar 0,459 atau $45,9 \%$. Bentuk hubungan keterkaitan harga lahan adalah negatif. 


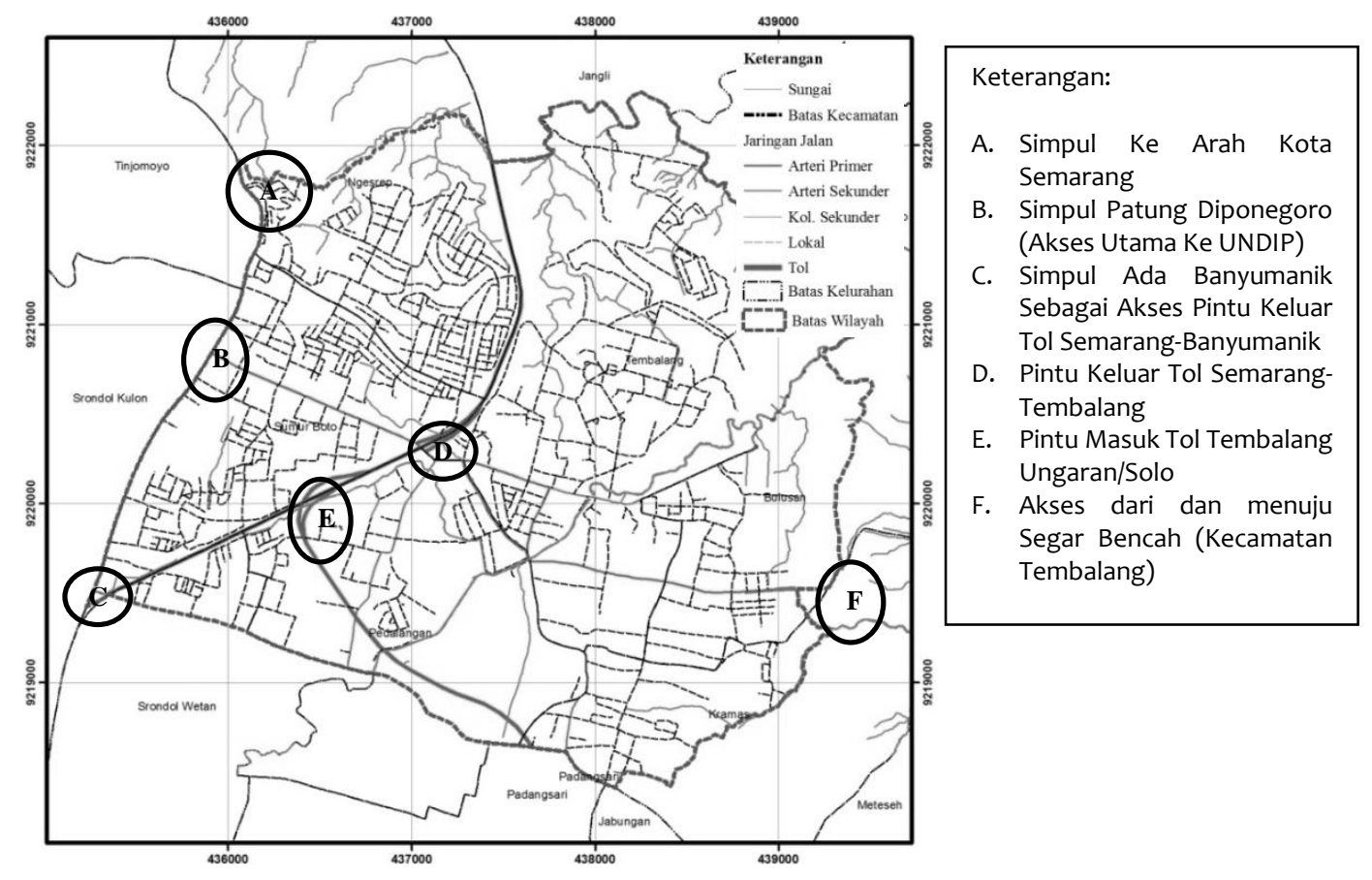

Gambar 5. Aksesibilitas Kawasan Tembalang

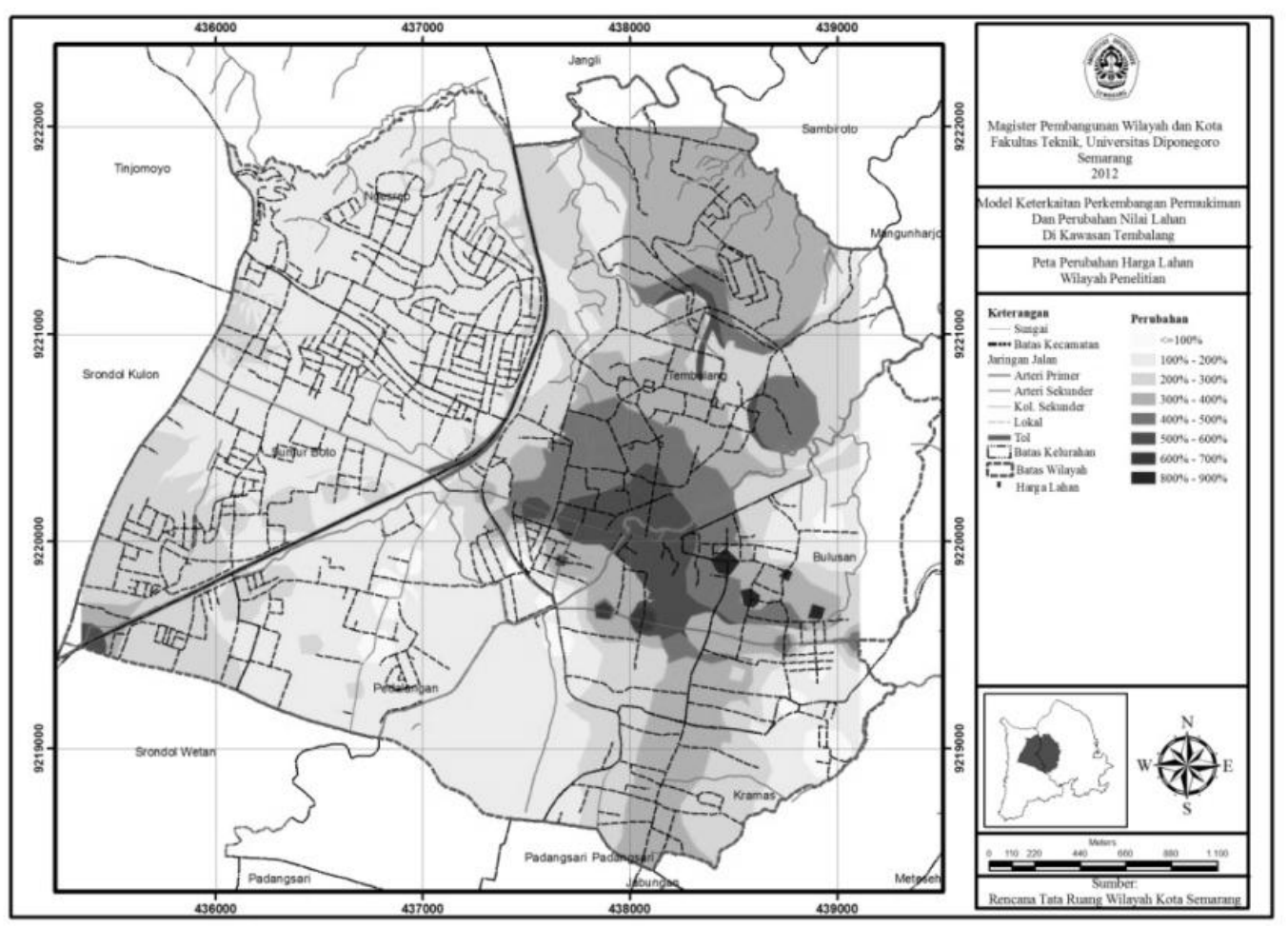

Gambar 6. Perubahan Harga Lahan Kawasan Tembalang 


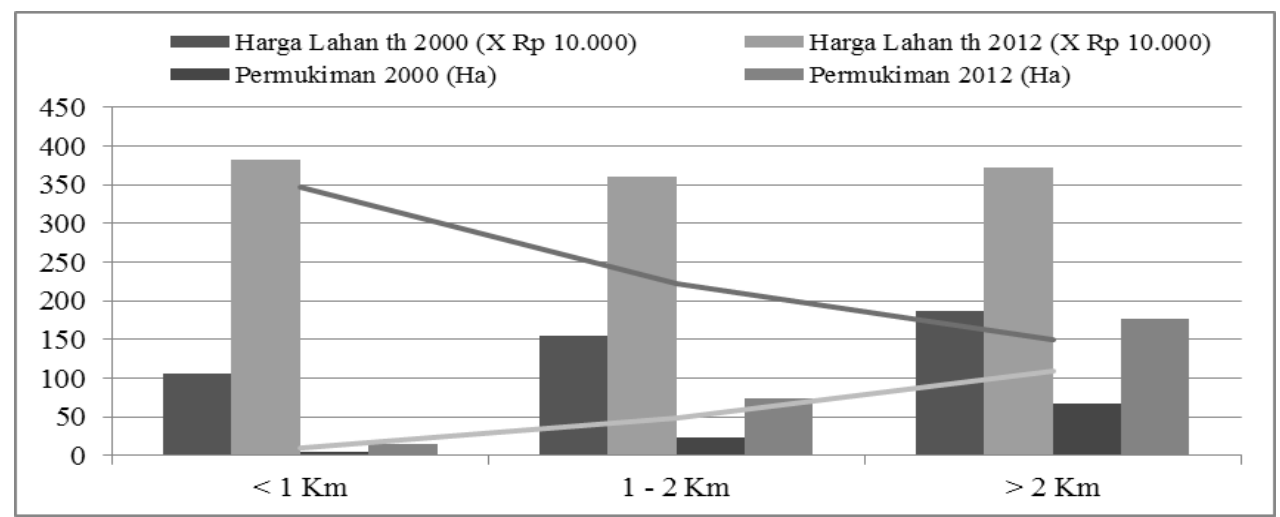

Gambar 7. Grafik Perkembangan Permukiman dan Perubahan Harga Lahan

Tabel 1. Parametrict Correlations

\begin{tabular}{l|l|r|r}
\hline & Parametrict Correlations & \multicolumn{1}{|c|}{ Harga } & Permukiman \\
\hline \multirow{4}{*}{ Harga } & Pearson Correlation & 1 & $-.459^{*}$ \\
\cline { 2 - 4 } & Sig. (2-tailed) & & .011 \\
\cline { 2 - 4 } & Sum of Squares and Cross-products & 103.867 & -4479.933 \\
\cline { 2 - 4 } & Covariance & 3.582 & -154.480 \\
\cline { 2 - 4 } & $\mathrm{N}$ & 50 & 50 \\
\hline \multirow{3}{*}{ Permukiman } & Pearson Correlation & $.459^{*}$ & 1 \\
\cline { 2 - 4 } & Sig. (2-tailed) & .011 & \\
\cline { 2 - 4 } & Sum of Squares and Cross-products & -4479.933 & 918572.967 \\
\cline { 2 - 4 } & Covariance & -154.480 & 31674.930 \\
\cline { 2 - 4 } & $\mathrm{N}$ & 50 & 50 \\
\hline
\end{tabular}

*. Correlation is significant at the 0.05 level (2-tailed)

Dari gambar 7, terlihat perkembangan permukiman berbanding terbalik dengan jarak dari pusat kawasan. Perubahan harga lahan cenderung berbanding lurus dengan radius jarak dari pusat kawasan. Temuan ini mengindikasikan adanya pengaruh negatif dari perubahan harga lahan terhadap perkembangan permukiman. Perkembangan permukiman umumnya berada di daerah dengan harga lahan yang relatif lebih murah. Sedangkan perkembangan permukiman menjadi salah satu faktor pendorong dari peningkatan harga lahan, khususnya terlihat di Kelurahan Bulusan adanya perkembangan permukiman yang signifikan memberi dorongan pada peningkatan harga lahan.

\section{Kesimpulan}

Kesimpulan dari penelitian yang dilakukan adalah

1. Perkembangan Permukiman

Perkembangan permukiaman di kawasan Tembalang dapat dikatakan terfokus pada radius 1-2 $\mathrm{km}$ dari pusat kawasan. Dua dimensi utama yang mempangeruhi perkembangan permukiman di Kawasan Tembalang adalah dimensi lokasi dan dimensi perumahan, selain dimensi siklus kehidupan dan dimensi pengahasilan (Turner, 1976). Perkembangan permukiman di Kawasan Tembalang di pengaruhi 
oleh aksesibilitas dan fungsi pendidikan tinggi yang menjadi bentuk daya tarik kawasan, selaian itu pertumbuhan permukiman teratur sendiri juga mendukung munculnya permukiman di sekitarnya.

2. Perubahan Harga Lahan

Perubahan harga lahan yang sangat signifikan di Kawasan Tembalang Khususnya di wilayah sekitar Kawasan UNDIP sebagai pusat Kawasan Tembalang dikarenakan beberapa akibat, selain perkembangan Kawasan Tembalang. Faktor lokasi dan jarak dari kawasan undip dinilai menjadi faktor utama, terlihat dari grafik rata rata perubahan harga lahanberbanding terbalik dengan jarak dari pusat kawasan.

Nilai strategis suatu lahan juga memberi dampak positif pada perubahan harga lahan, seperti ditemukan di beberapa bagian kawasan yang memiliki pertumbuhan nilai aksesibilitas, karena pembangunan jalan baru atau peningkatan kualitas jalan.

3. Keterkaitan Perkembangan Permukiman dan perubahan Nilai Lahan

Kesimpulan dari hasil uji korelasi parametrik dan koralasi non parametrik menunjukan adanya keterkaitan antara perkembangan permukiman dengan perubahan nilai lahan atau sebaliknya. Besar korelasi berkisar antara 0,45-0,459. Perkembangan permukiman terhadap harga lahan bernilai positif, sedangkan pengaruh harga lahan terhadap permukiman bernilai negatif, dalam artian perkembangan permukiman cenderung berada di harga lahan rendah

Beberapa rekomendasi berdasarkan hasil analisis dan simpulan diatas adalah:

1. Perkembangan permukiman di Kawasan Tembalang yang berkembang dengan memanfaatkan ruang terbuka dan lahan pertanian mengancam ekologi lingkungan, dampak lanjut adalah okupansi pada ruang terbuka yang terus berkurang. Pemerintah, khususnya pemerintah Kota Semarang perlu melakukan kajian lebih jauh mengenai alih fungsi lahan pertanian dan ruang terbuka yang umumnya berkembang menjadi permukiman dan fasilitas pendukungnya.

2. Harga lahan yang digunakan dalam penelitian ini merupakan harga pasar, sehingga kajian lanjut mengenai Nilai Jual Objek Pajak perlu diperhitungkan. Harga lahan dalam pembangunan berimplikasi pada tahap awal pembangunan, seperti pembebasan lahan, harga lahan yang terlalu tinggi akan menghambat pembangunan, khususnya infrastruktur non-profit. Selanjutnya hasil penelitian ini diharapkan dapat membantu pemerintah dalam penentuan nilai jual objek pajak (tanah).

\section{Daftar Pustaka}

Doxiadis. 1974. Action for A Better Scientific Approach to The Subject of Human Settlements, The journal of ekistics, volume 38 No. 229 Desember 1974

Ernawati, Ririn. 2005. Studi Pemodelan Nilai Tanah di Kota Tulungagung Kabupaten Tulungagung. Malang : Skripsi Fakultas Teknik Universitas Brawijaya

Jayadinata, J.T. 1999. Tata Guna Tanah dalam Perencanaan Pedesaan Perkotaan dan Wilayah. Bandung: ITB

Pigawati Bitta dan Iwan Rudiarto.2011. Penggunaan Citra Satelit Untuk Kajian Perkembangan Kawasan Permukiman Di Kota Semarang. Forum Geografi, Vol. 25, No. 2, Desember 2011: 140 - 151

Riza, Moch. 2005. Aplikasi Sistem Informasi Geografis untuk Pembuatan Nilai Jual Obyek Pajak (NJOP) Bumi di Kota Surabaya. Surabaya : Program Studi Teknik Geodesi FTSP-ITS.

Sutrisno. 2007. Manajemen Keuangan. Yogyakarta: Ekonesia 